\title{
The Efficacy of the DNA Act and DNA Database in South Korea
}

\author{
Min-Young Choi*
}

\section{Overview of the DNA Act of Korea}

The Act on Use and Protection of DNA Identification Information (DNA Act) of the Republic of Korea was legislated in January 2010, with the purpose of 'contributing to investigations and prevention of crimes and the protection of citizens' rights and interests by providing for matters necessary for the collection, use, and protection of DNA identification information (DNA information). ${ }^{1}$ The adoption of the Act took 15 years, long enough time to witness various opinions and different versions of the bill. One of the most notable and heatedly debated issues was the 'protection of basic rights vs. efficiency of apprehending criminals and prevention of recidivism'. The rationale behind the DNA Act is to arrest a perpetrator by quickly identifying him/her through comparison of DNA information against the registered database when a violent crime occurs, while eliminating innocent people in the early stages and ensuring the prevention of recidivism of people whose DNA information is already within the registry. In short, the Act aims to increase the efficiency of arresting criminals and prevent future crimes. However, the Act also received backlash due to the violation of basic rights, such as the right to self-determination of personal information, with regards to specific details of a list of crimes where sample collection is permitted, the scope of offenders subject to collection, the legal basis of the DNA sample collection and analysis, and the destruction of DNA samples and information. Furthermore, a more fundamental question has also been asked about the efficacy of the DNA database: does it really prevent recidivism? ${ }^{2}$ A look at the details of the DNA Act will help clarify these issues.

According to the Act, DNA samples can be collected from prisoners, detained suspects and at crime scenes. ${ }^{3}$ For the first two occasions, a court-issued warrant is required. However, in case the person subject to the collection consents to the collection in a written document, no warrant is necessary. The DNA information obtained through identification of DNA is registered in the database. In doing so, the DNA sam-

DOI: $10.21552 / \mathrm{edpl} / 2019 / 4 / 5$

* Dr. jur. Min-Young Choi, Research Fellow, Korean Institute of Criminology, Seoul, South Korea. For correspondence: $<$ minyoungchoi@kic.re.kr>.

1 DNA Act, art 1.

2 Choi Min-Young, 'The DNA Identification Act in South Korea: Issues of Justifiability and Efficacy' (December 2015) 15(1) Journal of Korean Law 157-190.

3 DNA Act, arts 5, 6 and 7. The 'Crime scene, etc' refers to 'a thing discovered at a crime scene, at the exterior or interior of the victim's body or the body, object of a person, or a place related to the crime.' 
ples and DNA collected from them must be destroyed without delay. ${ }^{4}$ Initially, the DNA Act only listed 11 types of crimes subject to samples collection, ${ }^{5}$ but a later amendment added 7 more types of crimes: bodily injury and violence, false arrest and illegal confinement, intimidation, intrusion upon habitation, obstructing of exercise of rights, fraud and extortion, and destruction and damage. The DNA information registered in the database may be subject to search and reply in certain cases by the person in charge of DNA identification information. ${ }^{6}$ The person in charge of the DNA must, ex officio or at the request of the person in question, expunge the DNA information from the database in the following cases: a judgment for acquittal, exoneration, and dismissal of prosecution is finally and conclusively affirmed in a retrial of a prisoner; a disposition of a prosecutor for 'cleared of suspicion' is made for a detainee; or a court decision of acquittal, exoneration and dismissal of prosecution is finally and conclusively made. In case the prisoner or detainee passes away, the DNA information must also be deleted either ex officio or at the request of the next of kin. The DNA information obtained from crime scenes must be erased when the identity is ascertained. ${ }^{7}$ Currently, the DNA database is under dual management system run by both the Prosecutor General of the Public Prosecutors' Office and the Commissioner General of the National Police Agency, which are clearly listed as the two administrative heads under the DNA Act. The former is in charge of DNA information obtained from prisoners, while the latter is responsible for DNA information from detained suspects and crime scenes. The two databases may be linked together in operation. ${ }^{8}$

\section{Prima Facie Consent on Efficacy, and Continued Debate on Justifiability}

The contradiction between the two aspects - protection of basic rights vs. efficiency of apprehending criminals and prevention of recidivism - has persisted since the establishment of the Act. Indeed, two constitutional adjudications were made in 2014 and 2018 on two claims that articles of the DNA Act infringed upon the basic constitutional rights of the claimants. In the first request, the following articles were claimed to be unconstitutional: the collection of DNA samples from a person to whom final and conclusive court decision is made on specific crimes; sample collection based on a courtissued warrant and written consent; identification of the DNA sample; registration of the DNA information and management of the DNA registry; DNA information search and reply; expunging of DNA information in case of the death of a person; and retroaclarceny, special larceny and robbery, f) assault, intimidation, arrest, detention, destruction and damage, intrusion upon habitation, extortion committed habitually or in group, and organization of a crime group under the Act on the Punishment of Violences, g) kidnapping and abduction, and habitual larceny and habitual robbery under the Act on Aggravated Punishment of Specific Crimes, $\mathrm{h}$ ) sexual crimes under the Act on Punishment of Sexual Assault, etc, i) narcotics crime under the Narcotics Act, j) sexual assault, prostitution, trafficking of and extortion against juveniles under the Act on the Protection of Children and Juveniles against Sexual Abuse, $\mathrm{k}$ ) murder of superiors and sentry, and arson under the Military Criminal Act.

6 'Certain cases' refers to: a) when new DNA identification information is stored in the database, b) when a prosecutor or police officer make a request for investigation of a crime or identification of a person who died unnatural cause, c) when a court sends an inquiry of facts during a criminal trial, and d) when it is necessary for cross reference between the databases.

7 DNA Act, arts 10,11 and 13 .

8 DNA Act, art 4. 
tive application of the Act. The Constitutional Court of Korea ruled against the claimant, adjudicating that all the articles in question were constitutional. ${ }^{9}$ The second request was made by those whose DNA samples were collected as per the warrant issued after a final court decision was made regarding the crime they committed. To their claim, the Constitutional Court adjudicated that the provision regulating the procedure of a warrant issuance was unconformable to the Constitution in that claimants were not given an opportunity to state their opinions during the issuance and that there is no process for challenging the issuance. ${ }^{10}$

Discussions regarding the DNA Act in Korea, including the decisions of the Constitutional Court, seem to generally accept the efficacy, or the objective, of the Act, which is effectiveness in apprehending criminals and preventing recidivism. Taking this assumption of efficacy for granted, critical analysis is focused on whether values including fundamental rights, warrant requirement and due process of law, and principle of innocent until proven guilty that can easily be violated by the DNA Act are legitimately protected under the principle of proportionality. In other words, DNA Act and the database set up by the Act, as effective as they are in crime investigation and prevention, must not infringe upon or limit the fundamental rights of a person and the basic principles of the Act of Criminal Procedure. The problem, however, is that a tangible discussion is almost non-existent regarding what exactly this efficacy entails and to what degree the DNA database is useful for the investigation of crimes and prevention of recidivism.

\section{What Is the Efficacy of the DNA Database?}

The debate on the efficacy of the DNA Act in Korea has unfolded in the context of the dual approach of DNA database management. From the early stages of legislation, the Act suffered from a tug of war between the Public Prosecutors' Office and the National Police Agency over the management jurisdiction of the database. This ultimately led to the split of management authority between the two organisations. The Government explained that linked management between the two will prevent inefficiency and the principle of checks and balances will also likely reduce possible abuse and misuse of the data. ${ }^{11}$ However, the consensus among the related criminal jurists is that management of the database should be under a single authority. The dualisation compromises effectiveness, wastes budget, and increases the risk of data misuse and abuse, as well as information leakage. Single authority management would be the right direction going forward not least because of the issue of efficiency. ${ }^{12}$ However, who is responsible for managing the database should be viewed from a different angle than the

2011 Hun Ma 28, 106, 141, 156, 326, delivered on 28 August 2014

Constitutional Court, 2016 Hun Ma 344, 2018 Hun Ma 630, delivered on 30 August 2018.

Legislation and Judiciary Committee, 'Review of Bill on Use and Protection of DNA Identification Information' (November 2009).

12 Seo Gae-Weon, 'Problem and Improvement for the Use and Protection of DNA Identification Act' (2010) 16(2) International Constitutional Law Review [in Korean]; Shin Yang-Kyun, 'The System of DNA Databank and Human Rights - Especially Considering Latest Enacted Use and Protection of DNA Act 2012' (2010) 22(3) Journal for Criminal Law [in Korean]; Cho Sung-Yong, 'A Critical Review on the Act on the Use and Protection of DNA Identification' (2010) 21(3) Korean Criminology Review [in Korean]. 
efficacy perspective: it is more of a realistic problem of conflict between the two government organisations.

As mentioned above, discussion on the efficacy of the database is rather scarce. Among what debates do occur, the efficacy of the database means the rate of arrests of offenders (detained suspects or convicted prisoners) whose DNA information matched that registered at the database obtained from the crime scene. However, this match rate, or the number of 'hits', has proven fairly low, ${ }^{13}$ which eventually led to the suggestion that the size of the database be expanded, while at the same time the utilisation rate of the information stored in the database be improved further. ${ }^{14}$ In order to achieve the former, the scope of persons and crimes subject to the DNA sample collection should be broadened, and for the latter, the recidivism rate may also be individually assessed when registering and deleting the information. However, serious policy consideration and discussion have not occurred regarding how much the database must be expanded to improve the match rate. Unlimited expansion will once more trigger a claim for unconstitutionality of the DNA Act. Furthermore, no one can guarantee that the extension in scope will directly translate into a better match rate. On the other hand, the latter suggestion of improving the utilisation level of the information in the database is worth noting. The list of crimes subject to DNA collection under the DNA Act is not based on the prediction of recidivism rate of individual offenders but rather on the statistics showing a certain type of crimes with higher repeat rate. The DNA information of detained suspects and convicted prisoners will in principle be stored permanently until their death without considering any unique characteristics of those persons. Merely registering and storing information not based on individual recidivism risk assessment will contribute to increasing the size of the database in the immediate short term, but it may also seriously undermine the overall efficacy. Therefore, the DNA Act needs amending so that individual recidivism risk assessment could become possible in case of collecting and deleting DNA samples. This could bring two-fold benefits: increasing the actual efficacy of the database, and securing the justifiability of the DNA Act.

But such discussion and alternative do not give satisfactory answer to the question 'what is the efficacy of the database?' The match rate, for starters, which is being used as the standard of efficacy does not show how many guilty suspects were arrested and convicted. DNA information may help identify persons suspected of committing a crime or those who have nothing to do with the crime. However, rarely does the information become the only or main factor in determining guilt, which makes it hard to confirm that it contributes to the rate of conviction. ${ }^{15}$ In addition, no evidence has been established yet that the DNA database is actually effective in preventing future crimes. It is normally thought that persons whose DNA information is already regis-

\footnotetext{
13 For instance, the number of information obtained from crime scenes and registered at the database from 2010 to 2014 amounts to 47,922, but the match between the data and the information from detained suspects or convicted prisoners was only 6,353 hits, which translates into a mere $13 \%$ match rate.

14 Kim Taek-Su, 'Legal Policy to Enhance the Effectiveness of DNA Database in Korea' (2015) 17(3) Korean Journal of Comparative Criminal Law [in Korean].

15 Sheldon Krimsky and Tania Simoncelli, Genetic Justice (Columbia University Press 2011) 305 et seqq.
} 
tered in the database will not commit crimes out of fear that they might be arrested again. However, it can hardly be called a conventional wisdom that can apply to countless innocent people who will never even attempt to deviate or to potential criminals who will act compulsively or will find clever ways to commit crimes. Considering all these, more fundamental reflection is needed as regards the standard of evaluating the efficacy of the database. If the assessment standard is more persuasive and appropriate, would it not to a certain degree resolve various doubts surrounding the justifiability of the DNA Act? The ongoing debate over the constitutionality of the DNA Act tends to present justifiability and efficacy as two contradictory values. However, if a clear standard of evaluating the efficacy of the DNA database could be established, the two aspects will no longer have to be perceived as non-reconcilable and mutually exclusive. 